\title{
Indonesia - The Trans Pacific Partnership Trade Potential
}

\author{
Juwita Puteri Nuraisyah \\ Graduate Programme in Economics \\ Faculty of Economics and Business, Universitas Indonesia \\ Indonesia \\ puteri.juwita@gmail.com
}

\begin{abstract}
This study investigates Indonesia's trade potential with the TPP economies. Covering 23 years (1992-2014) unbalanced panel data, this paper utilizes a gravity model where the trade potential is calculated from the estimated equation using the ratio of predicted and actual trade $(\mathrm{P} / \mathrm{A})$, and the speed of convergence (SC) method. Indonesia's trade potential is divided into agricultural and industrial goods; a comparison is made between Indonesia's trade with each of the TPP, ASEAN, and ASEAN+6 in turn. According to the ratio (P/A), the highest potential trading partner is Mexico; while based on the SC method, Indonesia has convergence in trade with Peru in both product groups. In the context of speed of convergence, Indonesia has the shortest time to reach its potential trade with Peru; and the longest time to reach convergence is Vietnam, in the agricultural sector.
\end{abstract}

Keywords-TPP; gravity model; trade potential

\section{INTRODUCTION}

Indonesia's intention to join the TPP, as declared in October 2015 by Indonesian President Joko Widodo, has triggered a heated debate on whether Indonesia should join the TPP or not. As Kim [1] mentioned Indonesia is one of the significant absent members from the TPP along with China and Korea. The Asian Development Bank (ADB) Institute study by Cheong [2] in 2013 demonstrated that non-member economies, such as Indonesia, can encounter economic losses compared to other more-competitive countries who are the members of TPP. For example Malaysia and Vietnam, which are well known as large manufacturers in textile markets, have more advantages in term of market access and tariff reductions. However, as stated in The Jakarta Post - Academic Opinion by Sahu [3], the World Integrated Trade Solutions (WITS) estimation model between Indonesia and the TPP members revealed that there would be $\$ 1.6$ billion surplus in trade in goods for Indonesia if the TPP came effective without Indonesia. Nevertheless, Indonesia's surplus in trade would become \$19 million deficit if Indonesia joined the TPP.

Recently, the Trans-Pacific Partnership (TPP) has become a prominent topic among analysts and editorialists. Nonetheless, academic research on the TPP issue is less established due to the progress of the TPP negotiations, which makes researchers encounter different variables and conditions depending on the year of their studies. The TPP literature is usually policy- oriented and analytically based, concentrating on economic and trade impacts.

Current literature on the TPP mostly uses an analytical approach. For example, Kim [1] analyzed the concept of the Chinese integration effort within the Association of Southeast Asian Nations (ASEAN) region concentrating on the comparative study of the TPP and Regional Comprehensive Economic Partnership $\left(\mathrm{RCEP}^{1}\right)$; Messerlin [4] aimed to examine the effects of the TPP pact on the European Union (EU) economy; while Williams [5] gave a comparative economic analysis of the TPP nations and their economic relations with the United States (U.S.).

Nevertheless, there are an emerging number of studies which quantified the potential TPP effects on economic in both member and non-member economies. Some studies focused on specific countries utilizing a computable general equilibrium (CGE) models: e.g., Itakura and Lee [6] emphasized in Japan; and Li and Whalley [7] highlighted the effects in China. While other studies gave a broader scope regarding TPP with other group countries, e.g., Cheong [2] analyzed the East Asian economic integration; and Petri et al. [8] examined the TPP and Asian Pacific countries. There are also researches applying other methods, such as Yeboah et al. [9] who investigated the potential impact of the TPP on U.S. agricultural trade using panel vector autoregression (VAR) and impulsed response function (IRF) models; and Karacaovali and Talagi [10] who studied the impacts of current intra-TPP and extra-TPP free trade agreements (FTAs) on the trade of the twelve TPP nations from 1980 to 2015 using a gravity model.

Furthermore, the analytical and empirical studies specific to Indonesia are still limited in number. One analytical study by Syadullah [11] strived to provide analysis about the profits and losses for Indonesia in joining the TPP agreement. He used a qualitative methodology by reviewing numerous of TPPrelated scientific research papers and research reports.

Many researchers have attempted to quantify the potential TPP effects. However, there is only one study trying to analyze the trade potential related to the TPP. The study was presented by Devadason [12], using an augmented panel gravity model. Trade potential is defined as the ratio between predicted value

1 A multilateral trade framework involving China, India, South Korea, Australia, New Zealand, Japan and the 10 members of the ASEAN, where it equals with ASEAN+6. 
and actual value of trade (between two regions or countries, based on their economic, geographic, and cultural characteristics, if they both are market economies). There is room for growth if the ratio exceeds 1 [13]. There is a wealth of empirical studies regarding trade potential, such as Trung and Thu [14], Gul \& Yasin [15], Kaur and Nanda [16], Batra [17], Montanari [13], and Jakab et al. [18].

Considering the fact that most of the TPP countries are already members of other FTAs in which Indonesia is also a party, this study addresses "What is the trade potential for Indonesia with the TPP economies?" as a research question. Therefore, the purpose of this study is to examine whether Indonesia has fully acknowledged its potential in trading with the TPP nations. The determinants explaining Indonesia's trade relation are estimated using a gravity model. Then, from the estimated equation, the ratio of predicted and actual trade (P/A) and the speed of convergence (SC) method are utilized to calculate trade potential of Indonesia with the TPP members and compares it to the trade potentials of Indonesia - ASEAN and Indonesia - ASEAN+6.

\section{RESEARCH METHOD}

To investigate the impacts of economic determinants on bilateral trade relations among Indonesia and the TPP countries, this study follows the extended gravity model used by Devadason [12]. This model was developed by Wang et al. [19], where the explanatory variables were based on Baltagi et al. [20] and Egger [21].

The equation is specified as follows:

$$
\begin{aligned}
\ln \text { TRADE }_{i t}= & \beta_{1} \text { ln GDPT }_{i t}+\beta_{2} \text { SIMGDP }_{i t}+\beta_{3} \ln G D_{i}+\beta_{4} \ln \\
& F D S T_{i t}+\beta_{5} \text { SIMFDST }_{i t}+\beta_{6} \text { RLFAC } \\
& \text { DUMContig }_{i}+\beta_{7} \\
& \text { DUMComlang }_{i}+\zeta_{t}+\varepsilon_{i t} \text { DUMLand }
\end{aligned}
$$

The explained variables in this study: $\ln T R A D E_{i t}$ is Indonesia's trade with country $i$ (partner) in natural logarithm form in year $t$. As suggested by Sohn [22], the trade model equation above is notably essential when a gravity model is implemented to a single-country, rather than country pairs. The description of each explanatory variable along with their expected values is defined in the Table 1 . In equation (1), $\beta$ denotes the coefficient estimates, $\zeta_{t}$ represents time effects, and $\varepsilon_{i t}$ is a term for white-noise disturbance.

The data employed in this study covers 23 years over the period of 1992-2014 (annual). The reason for choosing 1992 as the starting year is that the FTA within ASEAN named ASEAN Free Trade Area (AFTA) was in force in January 1992. Due to lack of required data ${ }^{2}$, the analysis is based on the sample for Indonesia's trade with 12 TPP members, 8 nations of the ASEAN and 14 countries of the ASEAN+6.

\footnotetext{
${ }^{2}$ Initially the dataset in this study included Indonesia's trade with 12 countries of the TPP; Indonesia's trade with 9 countries of the ASEAN; and Indonesia's trade with 15 countries of the ASEAN+6. However, Myanmar was excluded due to lack of required data.
}

TABLE I. DESCRIPTION OF EXPLANATORY VARIABLES AND EXPECTED SIGNS

\begin{tabular}{llc}
\hline $\begin{array}{c}\text { Explanatory } \\
\text { Variables }\end{array}$ & \multicolumn{1}{c}{ Description } & $\begin{array}{c}\text { Expected } \\
\text { Sign }\end{array}$ \\
\hline In GDPT & $\begin{array}{l}\text { Total GDP of Indonesia and partner country } \\
\text { in natural logarithm form }\end{array}$ & + \\
SIMGDP & $\begin{array}{l}\text { Similarity in the levels of GDP in Indonesia } \\
\text { and partner country } \\
\text { Geographical distance between Indonesia and }\end{array}$ & + \\
ln GD & $\begin{array}{l}\text { partner country in natural logarithm form } \\
\text { Total inward FDI stock of Indonesia and } \\
\text { partner country in natural logarithm form }\end{array}$ & + \\
SIMFDS & $\begin{array}{l}\text { Similarity in inward FDI stocks in Indonesia } \\
\text { and partner country }\end{array}$ & + \\
RLFAC & $\begin{array}{l}\text { Relative factor endowments in Indonesia and } \\
\text { partner country }\end{array}$ & + +- \\
Dummy variable is equal to 1 if Indonesia \\
and partner country are contiguous, and 0 \\
otherwise
\end{tabular}

\section{A. Estimator for the Gravity Model}

Fixed effects (FE) and random effects (RE) models are often used to estimate panel gravity models. However, if FE model is employed in the gravity model, it has several downsides. For example, FE model is incapable to estimate the effects of time invariant regressors, e.g., distance, common border, common language, etc., which was proved by Egger [21]. In addition, the FE and RE models follow $u_{i j, t} \sim i i d\left(0, \sigma^{2}\right)$, where iid means independently and identically distributed. Therefore, it implies homoscedasticity, no autocorrelation and no contemporaneous correlation within the panel [23]. Practically, panel data often deals with these problems. Hence, FE and RE models are not reliable for panel with crosssectional dependence.

As demonstrated by Beck \& Katz [24], Prais-Winsten regression transformed the model to account for a first-order autoregressive $[A R(1)]$ process. The standard errors are calculated from a variance covariance matrix that corrects for heteroskedasticity and contemporaneous correlation among the residuals. The results are unbiased coefficients and consistent panel-corrected standard errors (PCSE). Besides, in the case of the panel size is not large enough; the results of Prais-Winsten with PCSE regressions will be suitable. In conclusion, if the residual terms fail the iid assumption, i.e., if the residuals are heteroscedastic across panels or heteroscedastic and contemporaneously correlated across panels, with or without $A R(1)$, the Prais-Winsten with PCSE regression is preferable. As a result, this study employs Prais-Winsten with PCSE as the estimator.

\section{B. The Trade Potential}

Indonesia's trade potential is divided into two product groups based on Harmonized System (HS) 2012, HS01-HS24 for agricultural and HS25-HS97 for industrial goods. Then comparison is made between Indonesia's trade with each of the TPP, ASEAN, and ASEAN+6 in turn. In addition, it should be 
noted that due to the data constraint, the set-up of the gravity equation is unbalanced.

From the equation (1), the estimated coefficients are utilized to predict the trade volume between Indonesia and 3 FTA groups. The ratio of trade potential is predicted by the model $(\mathrm{P})$ and actual trade $(\mathrm{A})$, i.e., $(\mathrm{P} / \mathrm{A})$. If the value of $\mathrm{P} / \mathrm{A}$ is bigger than one, then there is potential expansion of trade with the partner country.

In addition, to calculate trade potential, this study also follows Jakab et al. [18] using the method of the speed of convergence (SC). This SC method is to counter critics for lacking theoretical justifications as Egger [21] explained that the difference between trade potential and actual trade value is an indicator of the model misspecification.

The formula for calculating the SC is described as follows:

$$
\begin{aligned}
S C= & {[\text { (Average growth rate of predicted trade } \div \text { Average }} \\
& \text { growth rate of actual trade }) \times 100]-100
\end{aligned}
$$

If the average growth rate of predicted trade is smaller than the actual trade, SC will be negative indicating the convergence. On the contrary, the positive value of SC shows the divergence of trade. Comparing to the analysis of point estimates [the difference $(\mathrm{P}-\mathrm{A})$ or ratio $(\mathrm{P} / \mathrm{A})$ ], estimated results obtained from this method are more valid due to the exploitation of the dynamic structure of the data during this estimation [18]. As proposed by Jakab et al. [18], this study applies a simple error correction regression model to estimate the convergence of the actual Indonesia's trade towards the estimated equilibrium:

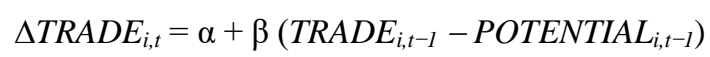

where $\triangle T R A D E_{i, t}$ is change in actual trade values of Indonesia and partner country; and $\left(T_{R A D E_{i, t-1}}-\right.$ POTENTIAL $\left._{i, t-1}\right)$ is the difference between actual (A) and predicted (P) trade of Indonesia and partner country in the previous period. Convergence will exist if the estimated coefficient $\beta$ is negative and significant.

\section{RESULTS AND DISCUSSION}

The trade potential is estimated by keeping all the explanatory variables. Moreover, the analysis is categorized into two product groups, HS01-HS24 for agricultural and HS25-HS97 for industrial goods; they are estimated separately for each FTA group.

First, the results of using the trade potential (P/A) ratio are shown in Table 2. The highest potential trading partner for Indonesia - TPP is Mexico, followed by Brunei Darussalam. The trade potential for Indonesia also appears with Australia specifically in industrial goods; while with Vietnam and Japan in agricultural goods. Although the overall results of Chile and Peru are below one, the trade potential arises in agricultural and industrial goods, respectively. Meanwhile, the ratio (P/A) for Canada, Malaysia, Singapore, and the U.S. is about 1 or lower, considering the data that these countries are included in Indonesia's top ten trading partners. Ratio $(\mathrm{P} / \mathrm{A})<1$ means that a dramatic increase in trade in the next years should not be expected, because those countries already exploit their predicted trade as defined by the model. As explained by Montanari [13], the predicted trade does not represent a precise estimate of a future value of trade flows, but rather a point of reference. Therefore, a lower-than-1 ratio does not imply that trade should actually decrease, but it can be concluded that the trade value is above norm.

\begin{tabular}{|c|c|c|c|c|c|c|}
\hline \multirow[b]{2}{*}{ Variables } & \multicolumn{6}{|c|}{ Prais-Winsten with PCSE } \\
\hline & $\begin{array}{l}\text { Indones } \\
\text { (1) }\end{array}$ & $\begin{array}{r}a-\text { TPP } \\
(2) \\
\end{array}$ & $\begin{array}{c}\text { Indones } \\
\text { (3) }\end{array}$ & $\begin{array}{c}\text { ASEAN } \\
\text { (4) }\end{array}$ & $\begin{array}{c}\text { Indonesia - } \\
(5)\end{array}$ & $\begin{array}{c}\text { ASEAN+6 } \\
\text { (6) }\end{array}$ \\
\hline $\ln G D P T$ & $\begin{array}{c}1.681^{* * * *} \\
(0.0927)\end{array}$ & $\begin{array}{c}1.608^{* * *} \\
(0.112)\end{array}$ & $\begin{array}{c}0.981^{* *} \\
(0.443)\end{array}$ & $\begin{array}{c}-8.842 * * * \\
(1.776)\end{array}$ & $\begin{array}{c}1.793^{* * * *} \\
(0.0313)\end{array}$ & $\begin{array}{l}1.571 * * * \\
(0.0339)\end{array}$ \\
\hline SIMGDP & $\begin{array}{c}3.796^{* * * *} \\
(0.536)\end{array}$ & $\begin{array}{c}3.547^{* * * *} \\
(0.636)\end{array}$ & $\begin{array}{c}7.633^{* * * *} \\
(0.530)\end{array}$ & $\begin{array}{c}15.48^{* * * *} \\
(2.094)\end{array}$ & $\begin{array}{c}5.247 * * * \\
(0.324)\end{array}$ & $\begin{array}{c}3.733^{* * * *} \\
(0.281)\end{array}$ \\
\hline $\ln G D$ & $1.842^{* * * * *}$ & $1.934^{* * * *}$ & 0.414 & 0.282 & $-1.146 * * *$ & $-1.112 * * * *$ \\
\hline $\ln F D S T$ & $\begin{array}{c}(0.0902) \\
0.118^{*} \\
(0.0604)\end{array}$ & $\begin{array}{c}(0.119) \\
0.305^{* * * *} \\
(0.106)\end{array}$ & $\begin{array}{c}(0.304) \\
0.535^{* * * *} \\
(0.120)\end{array}$ & $\begin{array}{c}(0.305) \\
0.675^{* * *} \\
(0.163)\end{array}$ & $\begin{array}{c}(0.0627) \\
0.214 * * * \\
(0.0406)\end{array}$ & $\begin{array}{l}(0.0644) \\
0.678^{* * * *} \\
(0.0657)\end{array}$ \\
\hline SIMFDS & $\begin{array}{c}0.627 \\
(0.382)\end{array}$ & $\begin{array}{c}0.799 \\
(0.575)\end{array}$ & $\begin{array}{c}1.899 * * * \\
(0.524)\end{array}$ & $\begin{array}{c}1.576 * * * \\
(0.484)\end{array}$ & $\begin{array}{c}2.237 * * * \\
(0.405)\end{array}$ & $\begin{array}{c}3.265^{* * * *} \\
(0.415)\end{array}$ \\
\hline RLFAC & $\begin{array}{l}0.159 * * \\
(0.0680)\end{array}$ & $\begin{array}{c}0.0835 \\
(0.0884)\end{array}$ & $\begin{array}{c}0.390^{* * * *} \\
(0.0821)\end{array}$ & $\begin{array}{c}0.341 * * * \\
(0.0969)\end{array}$ & $\begin{array}{c}0.106 * * * \\
(0.0358)\end{array}$ & $\begin{array}{l}0.0579^{*} \\
(0.0330)\end{array}$ \\
\hline DUMContig & $\begin{array}{c}0.210 \\
(0.190)\end{array}$ & $\begin{array}{c}0.150 \\
(0.224)\end{array}$ & $\begin{array}{c}-0.421 * * * * \\
(0.134)\end{array}$ & $\begin{array}{c}-0.317^{* * * *} \\
(0.120)\end{array}$ & $\begin{array}{c}-0.559 * * * * \\
(0.123)\end{array}$ & $\begin{array}{c}-0.536 * * * \\
(0.122)\end{array}$ \\
\hline DUMLand & 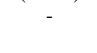 & 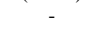 & $\begin{array}{c}-3.048^{* * * *} \\
(0.167)\end{array}$ & $\begin{array}{c}-3.080^{* * * *} \\
(0.163)\end{array}$ & $\begin{array}{c}-3.113 * * * * \\
(0.153)\end{array}$ & $\begin{array}{c}-2.987 * * * \\
(0.167)\end{array}$ \\
\hline DUMComlang & $\begin{array}{c}- \\
1.612^{* * * *} \\
(0.265)\end{array}$ & $\begin{array}{c}- \\
1.747^{* * * *} \\
(0.343)\end{array}$ & $\begin{array}{c}0.870^{* * *} \\
(0.274)\end{array}$ & $\begin{array}{c}0.643^{* *} \\
(0.309)\end{array}$ & $\begin{array}{c}0.292 \\
(0.190)\end{array}$ & $\begin{array}{c}0.185 \\
\\
(0.208)\end{array}$ \\
\hline Constant & $\begin{array}{c}12.22^{* * * *} \\
(2.100)\end{array}$ & $\begin{array}{l}11.20^{* * * *} \\
(2.462)\end{array}$ & $\begin{array}{l}-18.00^{*} \\
(10.88)\end{array}$ & $\begin{array}{c}242.7 * * * \\
(49.50)\end{array}$ & $\begin{array}{c}-23.62 * * * \\
(0.600)\end{array}$ & $\begin{array}{r}-22.27 * * * \\
(0.621)\end{array}$ \\
\hline $\begin{array}{l}\text { Observations } \\
\text { R-squared }\end{array}$ & $\begin{array}{c}274 \\
0.974\end{array}$ & $\begin{array}{c}274 \\
0.978\end{array}$ & $\begin{array}{c}173 \\
0.949\end{array}$ & $\begin{array}{c}173 \\
0.967\end{array}$ & $\begin{array}{c}311 \\
0.937\end{array}$ & $\begin{array}{c}311 \\
0.950\end{array}$ \\
\hline $\begin{array}{l}\text { Number of } \\
\text { Countries } \\
\text { Year effects }\end{array}$ & $\begin{array}{c}12 \\
\mathrm{NO}\end{array}$ & $\begin{array}{c}12 \\
\text { YES }\end{array}$ & $\begin{array}{c}8 \\
\text { NO }\end{array}$ & $\begin{array}{c}8 \\
\text { YES }\end{array}$ & $\begin{array}{c}14 \\
\text { NO }\end{array}$ & $\begin{array}{c}14 \\
\text { YES }\end{array}$ \\
\hline
\end{tabular}

TABLE II. REGRESSION RESULTS - PRAIS-WINSTEN REGRESSIONS WITH PCSE

Comparing to the previous study by Devadason [12], the results of this research were found to be relatively different in term of the number of potential trading partners. Devadason found China had trade potential with 11 out of 12 countries of the TPP members. Meanwhile, this study found smaller number for Indonesia's trade potential with the TPP, which is 9 out of 12 countries. In addition, the results show that there is no dominant sector between agricultural or industrial goods in term of Indonesia's potential trading; unlike Devadason's study where it was found that China's potential export laid on the agricultural sector.

The results of trade potential of Indonesia with the three FTA groups, Indonesia - TPP, Indonesia - ASEAN and Indonesia - ASEAN+6, show some similarities for several partner countries, particularly to the TPP members who are also participants in ASEAN and ASEAN+6. The most obvious result is that the trade potential between Indonesia - Singapore and Indonesia - Malaysia in all FTA groups are below one; which indicates that the trading relations between Indonesia and these countries have reached their full potential. This is supported by the fact that Malaysia and Singapore are in the top ten exports and imports partners. Conversely, trade potential with Brunei Darussalam in all FTA groups is still under trading. Meanwhile, Indonesia's trade potential with Vietnam only exists in the TPP framework, specifically in agricultural goods. 
TABLE III.

CONVERGENCE OF ACTUAL TRADE TOWARDS POTENTIAL TRADE USING PRAIS-WINSTEN WITH PCSE

\begin{tabular}{|c|c|c|c|c|c|c|c|c|c|}
\hline & \multicolumn{3}{|c|}{ Indonesia - TPP } & \multicolumn{3}{|c|}{ Indonesia-ASEAN } & \multicolumn{3}{|c|}{ Indonesia - ASEAN+6 } \\
\hline VARIABLES & $1992-2014$ & $\begin{array}{l}\text { Agricultural } \\
1992-2014 \\
\end{array}$ & $\begin{array}{c}\text { Industrial } \\
1992-2014\end{array}$ & $1992-2014$ & $\begin{array}{l}\text { Agricultural } \\
1992-2014 \\
\end{array}$ & $\begin{array}{c}\text { Industrial } \\
1992-2014\end{array}$ & $1992-2014$ & $\begin{array}{l}\text { Agricultural } \\
1992-2014 \\
\end{array}$ & $\begin{array}{c}\text { Industrial } \\
1992-2014\end{array}$ \\
\hline $\begin{array}{l}\text { Difference between } \\
\text { actual and potential } \\
\text { trade }\end{array}$ & $-0.556^{* * *} *$ & -0.0448 & $-0.625 * * *$ & $-0.464 * *$ & $-0.433 * * *$ & $-0.449 * *$ & $-0.343^{* *}$ & -0.105 & $-0.240^{*}$ \\
\hline Constant & $\begin{array}{c}(0.143) \\
8.104 \mathrm{e}+08^{* *} \\
(3.937 \mathrm{e}+08)\end{array}$ & $\begin{array}{c}(0.0485) \\
5.093 \mathrm{e}+07 * \\
(2.737 \mathrm{e}+07)\end{array}$ & $\begin{array}{c}(0.160) \\
8.260 \mathrm{e}+08 * * \\
(3.840 \mathrm{e}+08)\end{array}$ & $\begin{array}{c}(0.181) \\
3.541 \mathrm{e}+08 \\
(3.816 \mathrm{e}+08)\end{array}$ & $\begin{array}{c}(0.113) \\
3.542 \mathrm{e}+07 \\
(4.486 \mathrm{e}+07)\end{array}$ & $\begin{array}{c}(0.187) \\
3.773 \mathrm{e}+08 \\
(3.615 \mathrm{e}+08)\end{array}$ & $\begin{array}{c}(0.136) \\
5.485 \mathrm{e}+08 \\
(5.634 \mathrm{e}+08)\end{array}$ & $\begin{array}{c}(0.0803) \\
7.484 \mathrm{e}+07 * \\
(3.868 \mathrm{e}+07)\end{array}$ & $\begin{array}{c}(0.136) \\
7.686 \mathrm{e}+08 * \\
(4.124 \mathrm{e}+08)\end{array}$ \\
\hline $\begin{array}{l}\text { Observations } \\
\text { R-squared } \\
\text { Number of } \\
\text { Countries }\end{array}$ & $\begin{array}{c}262 \\
0.244 \\
12\end{array}$ & $\begin{array}{c}262 \\
0.008 \\
12\end{array}$ & $\begin{array}{c}262 \\
0.266 \\
12\end{array}$ & $\begin{array}{c}165 \\
0.253 \\
8\end{array}$ & $\begin{array}{c}165 \\
0.214 \\
8\end{array}$ & $\begin{array}{c}165 \\
0.236 \\
8\end{array}$ & $\begin{array}{c}297 \\
0.152 \\
14\end{array}$ & $\begin{array}{c}297 \\
0.037 \\
14\end{array}$ & $\begin{array}{c}297 \\
0.085 \\
14\end{array}$ \\
\hline
\end{tabular}

Overall, the number of countries that have trade potential with Indonesia in the Indonesia - TPP which shows 9 out of 12 countries, is a bit bigger compared to the other two FTA groups. It suggests that Indonesia has not exploited all the potential in trading with the TPP countries. Moreover, the results of trade potential of Indonesia and each country in three FTA groups are consistent, except for Japan, New Zealand, and Vietnam where the results show differently between the Indonesia - TPP and Indonesia - ASEAN+6. Trade potential for Japan, New Zealand, and Vietnam exist in the Indonesia TPP.

Next, this study also applies the method of using the speed of convergence (SC) to estimate levels of trade as some kind of equilibrium level as suggested by Jakab et al. [18]. The convergence results of actual trade toward potential trade are available in Table 3. This study found significant convergence generally for all FTA groups using Prais-Winsten with PCSE estimation methodology. Hence, it can be inferred that bilateral trade flows between Indonesia and the three FTA groups are converging towards equilibrium, suggesting that the estimated potential trade results using the SC method are reliable and stable.

TABLE IV.

RATIO (P/A)

\begin{tabular}{|c|c|c|c|c|c|c|c|c|c|}
\hline & \multicolumn{3}{|c|}{ TPP } & \multicolumn{3}{|c|}{ ASEAN } & \multicolumn{3}{|c|}{ ASEAN +6} \\
\hline Country & $\mathrm{P} / \mathrm{A}$ & $\begin{array}{c}\mathrm{P} / \mathrm{A} \\
\text { Agricultural } \\
\end{array}$ & $\begin{array}{c}\mathrm{P} / \mathrm{A} \\
\text { Industrial }\end{array}$ & $\mathrm{P} / \mathrm{A}$ & $\begin{array}{c}\text { P/A } \\
\text { Agricultural } \\
\end{array}$ & $\begin{array}{c}\mathrm{P} / \mathrm{A} \\
\text { Industrial } \\
\end{array}$ & $\mathrm{P} / \mathrm{A}$ & $\begin{array}{c}\mathrm{P} / \mathrm{A} \\
\text { Agricultural } \\
\end{array}$ & $\begin{array}{c}\mathrm{P} / \mathrm{A} \\
\text { Industrial } \\
\end{array}$ \\
\hline Australia & 1.013 & 0.997 & 1.018 & - & - & - & 1.008 & 1.002 & 1.011 \\
\hline $\begin{array}{c}\text { Brunei } \\
\text { Darussalam }\end{array}$ & 1.031 & 1.056 & 1.026 & 1.014 & 1.010 & 1.017 & 1.020 & 1.047 & 1.020 \\
\hline $\begin{array}{c}\text { Danada } \\
\text { Canda }\end{array}$ & 0.995 & 0.974 & 0.997 & & - & - & - & - & - \\
\hline Cambodia & - & - & - & 1.004 & 1.004 & 1.006 & 1.026 & 1.017 & 1.051 \\
\hline Chile & 0.967 & 1.013 & 0.949 & - & - & 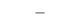 & & - & \\
\hline China & - & - & 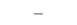 & - & - & - & 0.990 & 0.977 & 0.993 \\
\hline India & - & - & - & - & - & - & 1.030 & 0.964 & 1.056 \\
\hline Jap & 1.001 & 1.030 & 0.999 & - & - & - & 0.993 & 0.997 & 0.981 \\
\hline Korea & - & - & - & - & - & - & 0.994 & 1.081 & 0.987 \\
\hline Laos & - & - & - & 1.001 & 1.053 & 1.001 & 1.001 & 1.084 & 0.983 \\
\hline Malaysia & 0.999 & 0.999 & 0.999 & 1.000 & 1.000 & 1.000 & 1.000 & 0.999 & 0.999 \\
\hline Mexico & 1.032 & 1.079 & 1.026 & - & - & - & - & - & - \\
\hline $\begin{array}{c}\text { New } \\
\text { Zealan, }\end{array}$ & 0.995 & 0.969 & 1.001 & - & - & - & 0.996 & 0.971 & 0.990 \\
\hline $\begin{array}{l}\text { Lealand } \\
\text { Peru }\end{array}$ & 0.992 & 0.952 & 1.012 & - & - & - & - & - & - \\
\hline Philippines & - & - & - & 0.997 & 1.010 & 0.995 & 0.992 & 1.025 & 0.979 \\
\hline Singapore & 0.973 & 0.955 & 0.976 & 0.990 & 0.993 & 0.988 & 0.985 & 0.962 & 0.981 \\
\hline Thailand & - & - & - & 1.016 & 1.008 & 1.021 & 1.009 & 1.001 & 1.000 \\
\hline U.S & 0.989 & 0.972 & 0.988 & & 0 & 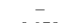 & - & - & 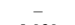 \\
\hline Vietnam & 1.002 & 1.009 & 0.995 & 0.981 & 0.974 & 0.978 & 0.964 & 0.966 & 0.939 \\
\hline
\end{tabular}

The results of SC calculation are displayed in Table 4. In general, using the SC method, the trade potential for Indonesia - TPP shows only 8 out of 12 countries which is smaller compared to the Indonesia - ASEAN+6 where it shows trade potential for 9 out of 12 countries. However, it still implies that Indonesia has not reached the full potential trading with the TPP members.

Furthermore, in particular, Indonesia's trade with TPP countries shows that Indonesia has convergence in trade with Peru in both product groups. Convergence also arises with Australia, Mexico, New Zealand, the U.S., and Vietnam in agricultural goods; and with Brunei Darussalam and Malaysia in industrial goods. Additionally, Indonesia has divergence in trade with Canada, Chile, Japan, and Singapore.

Nevertheless, in the context of speed of convergence of Indonesia's trade with the TPP members, Indonesia has the shortest time to reach its potential trade with Peru shown by the biggest negative value in term of its absolute value, which are $52.171,-60.435$, and -52.405 , for total trade, agricultural, and industrial goods, respectively. Meanwhile, the longest time to reach convergence is shown in the Indonesia's trade with Vietnam in agricultural goods; shown by the smallest negative value in term of its absolute value which is -11.565 .

In comparison for the TPP members who are also participants in ASEAN and ASEAN+6, Indonesia has only divergence trade with Singapore; meaning that Indonesia has over-traded with Singapore. The results of trade potential of -Indonesia and each country in the three FTA groups are consistent, except for Vietnam, where it displays convergence in the Indonesia - TPP and the Indonesia - ASEAN, but divergence in the Indonesia - ASEAN+6.

\section{CONCLUSION}

In summary, the Indonesia - TPP trade potential using the ratio (P/A) and the speed convergence (SC) method has demonstrated a slightly different result, where 9 and 8 countries out of 12 countries have trade potential with Indonesia, respectively. Nevertheless, it implies that Indonesia has not reached the full potential trading with the TPP members. According to ratio (P/A), the highest potential trading partner is Mexico; whereas based on the SC method, Indonesia has convergence in trade with Peru in both product groups. Therefore, Mexico and Peru are the most important partners that Indonesia should explore the full trade-potential. Nevertheless, in the context of speed of convergence, Indonesia 
has the shortest time to reach its potential trade with Peru; and the longest time to reach convergence is with Vietnam in agricultural sectors.

Additionally, the ratio (P/A) for Canada, Malaysia, Singapore, and the U.S. is about 1 or lower. Meanwhile, the SC method shows that Indonesia has divergence in trade with Canada, Chile, Japan, and Singapore. Ratio (P/A) $<1$ or divergence means that a dramatic increase in trade in the next years should not be expected, because those countries have already exploited their predicted trades as defined by the model. Hence, by looking at the similarities of the results, it is concluded that Indonesia has particularly overtraded with Canada and Singapore.

The results of trade potential of Indonesia and the three FTA groups (the Indonesia - TPP, Indonesia - ASEAN, and the Indonesia - ASEAN+6) show some similarities for several partner countries, particularly to the TPP members who are also participants in ASEAN and ASEAN+6. The most obvious result is the fact that the trade potential between Indonesia Singapore has no room for growth.

The significance of this study for policymakers is to maximize Indonesia's trade potential towards the TPP members so that it can bring diversification of trade for Indonesia. Nonetheless, since the TPP covers a wider range of issues compared to those covered by existing free trade agreements, not only trade in goods, services and investments, but also there are still many considerations for Indonesia to join the TPP, such as dispute settlement provisions for trade, investment, labor, and environment.

\section{REFERENCES}

[1] Kim, Y.-C. (2016). RCEP vs. TPP: The Pursuit of Eastern Dominance. In Chinese Global Production Networks in ASEAN (pp. 19-37). Springer International Publishing.

[2] Cheong, I. (2013). Negotiations for the Trans-Pacific Partnership agreement: Evaluation and implications for East Asian Regionalism. ADBI Working Paper 428. Tokyo: Asian Development Bank Institute. Retrieved from http://www.adbi.org/workingpaper/2013/07/11/5794.trans.pacific.partnership.east.asian.regionalism/

[3] Sahu, P. K. (2016, February 18). Insight: Trans-Pacific Partnership: Should Indonesia join it or not? Retrieved June 14, 2016, from http://www.thejakartapost.com/news/2016/02/18/insight-trans-pacificpartnership-should-indonesia-join-it-or-not.html

[4] Messerlin, P. (2013). The eu's strategy for Trans-Pacific Partnership. Journal of Economic Integration, 28(2), 285-302.

[5] Williams, B. R. (2013). Trans-Pacific Partnership (TPP) countries: comparative trade and economic analysis. Washington, DC: Congressional Research Service.
[6] Itakura, K., \& Lee, H. (2016). The Implications of the Trans-Pacific Partnership for Japan: Agricultural Policy Reforms and Productivity Gains. The 19th Annual Conference on Global Economic Analysis. Washington, DC: The World Bank.

[7] Li, C., \& Whalley, J. (2014). China and the Trans-Pacific Partnership: A numerical simulation assessment of the effects involved. World Economy, 37(2), 169-192.

[8] Petri, P. A., Plummer, M. G., \& Zhai, F. (2012). The Trans-pacific partnership and Asia-pacific integration: A quantitative Assessment (Vol. 98). Washington DC: Peterson Institute for International Economics.

[9] Yeboah, O. A., Shaik, S., \& Agyekum, A. F. (2015). Potential Impact of TPP Trade Agreement on US Bilateral Agricultural Trade: Trade Creation or Trade Diversion? In Southern Agricultural Economics Association's Annual Meeting. Atlanta, Georgia, January.

[10] Karacaovali, B., \& Talagi, D. (2017). International Trade Effects of Trans-Pacific Partnership for North America. Working Paper No. 17-1, University of Hawaii at Manoa, Department of Economics. Retrieved from https://ssrn.com/abstract=2927288

[11] Syadullah, M. (2016). Impact of the Trans Pacific Partnership to Indonesia. International Journal of Economics and Financial Issues, 6(4), 1366-1370.

[12] Devadason, E. S. (2014). The trans-pacific partnership (TPP): The Chinese perspective. Journal of Contemporary China, 23(87), 462-479.

[13] Montanari, M. (2005). EU trade with the Balkans: Large room for growth? Eastern European Economics, 43(1), 59-81.

[14] Trung, V. V., \& Thu, A. N. (2016, March). Trade potential of climate smart goods of Vietnam: An application of gravity model. Geographica Pannonica, 20(1), 8-18.

[15] Gul, N., \& Yasin, H. M. (2011). The trade potential of Pakistan: an application of the gravity model. The Lahore Journal of Economics, 16(1), 23-62.

[16] Kaur, S., \& Nanda, P. (2011). An Analysis of Actual and Potential Exports of Pakistan with SAARC Countries: A Panel Data Analysis. Pakistan Journal of Applied Economics, $1(1 \& 2)$, 69-91.

[17] Batra, A. (2006). India's global trade potential: The gravity model approach. Global Economic Review, 35(3), 327-361.

[18] Jakab, Z. M., Kovacs, M. A., \& Oszlay, A. (2001). How far has trade integration advanced?: An analysis of the actual and potential trade of three Central and Eastern European countries. Journal of Comparative Economics, 29(2), 276-292.

[19] Wang, C., Wei, Y., \& Liu, X. (2010). Determinants of bilateral trade flows in OECD countries: evidence from gravity panel data models. World Economy, 33(7), 894-915.

[20] Baltagi, B., Egger, P., \& Pfaffermayr, M. (2003). A generalized design for bilateral trade flow models. Economics Letters, 80, 391-397.

[21] Egger, P. (2002). An econometric view on the estimation of gravity models and the calculation of trade potentials. World Economy, 25(2), 297-312.

[22] Sohn, C.-H. (2005). Does the gravity model explain South Korea's trade flows? Japanese Economic Review, 56(4), 417-430.

[23] Kabir, M., \& Salim, R. (2010). Can Gravity Model Explain BIMSTEC's Trade?. Journal of Economic Integration, 25(1), 144-166.

[24] Beck, N., \& Katz, J. N. (1995). What to do (and not to do) with timeseries cross-section data. The American Political Science Review, 89(3), 634-647. 